\title{
Effect of Quaternary Phosphonium Salts in Organic Electrolyte for Lithium Secondary Batteries
}

\author{
Katsuhiko Tsunashima, ${ }^{\mathrm{a}, *}$ Fumihiro Yonekawa, ${ }^{\mathrm{b}}$ Masahiro Kikuchi, and Masashi Sugrya ${ }^{\mathrm{b}}$ \\ a Department of Materials Science, Wakayama National College of Technology (77 Noshima, Nada-cho, Gobo, \\ Wakayama 644-0023, Japan)

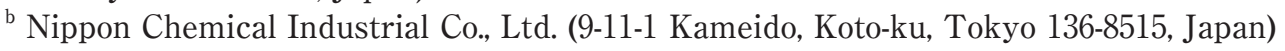

Received December 24, 2010 ; Accepted February 15, 2011

\begin{abstract}
Additive behaviors of several bis (trifluoromethylsulfonyl) amide-based phosphonium salts in an organic electrolyte used for lithium secondary batteries are reported. Electrolytic properties of a lithium hexafluorophosphatebased organic electrolyte mixed with the phosphonium salts were examined. It was found that the mixed electrolytes containing the phosphonium salts showed lower conductivities and higher viscosities than the organic electrolyte. However, in the case of the mixed phosphonium electrolytes based on asymmetrical cations, the charge-discharge cyclabilities of the lithium battery cells were superior to that of the cell containing the organic electrolyte. Furthermore, the thermal stability of $\mathrm{LiCoO}_{2}$ cathodes charged in the mixed phosphonium electrolytes was considerably improved. These results suggest that the phosphonium salts are regarded as effective electrolyte additives for lithium secondary batteries.
\end{abstract}

Key Words : Quaternary Phosphonium Salts, Lithium Secondary Battery, Electrolyte Additives, Thermal Stability

\section{Introduction}

Lithium secondary batteries are high-performance energy storage devices that have been employed as key components for portable electronic devices, electric vehicles, large-scale power systems, etc. In recent years, the practical use of electrolyte additives for lithium secondary batteries have been intensively studied from the viewpoint of improvement of cell properties such as charge-discharge capacity and cyclability, durability, overcharge safety, and so forth. ${ }^{1-3)}$ Many chemical compounds have been investigated as electrolyte additives on the basis of improvement of the charge-discharge performance. For instance, electrolyte additives based on quaternary ammonium salts to afford the high cycling efficiency have been proposed. ${ }^{4,5)}$ Hirai et al. reported that several quaternary ammonium compounds containing a long alkyl chain exhibited improving effects on the cycling properties of the lithium battery cells. ${ }^{4)}$ A quaternary ammonium salt based on a perfluorinated anion (tetraethylammonium perfluorooctanesulfonate) was also examined as a performance electrolyte additive for the improvement of cycling efficiency. ${ }^{5)}$ In both reports, it was demonstrated that the quaternary ammonium compounds significantly act as surfactants to give uniform films of lithium on the anode surface, suppressing the formation of needle-like lithium dendrites.

On the other hand, quaternary salts based on phosphonium cations have been regarded as the potential substitutes for the corresponding ammonium salts since it is well known that quaternary phosphonium compounds offer chemical and thermal stabilities as practical advantages. ${ }^{6.8)}$ From this point of view, quaternary phosphonium salts are of considerable interest for the battery electrolyte application. We have designed a new class of quaternary phosphonium compounds consisted of triethylphosphine $\left(\mathrm{C}_{2} \mathrm{H}_{5}\right)_{3} \mathrm{P}$ (TEP)- and tributylphosphine $\left(\mathrm{C}_{4} \mathrm{H}_{9}\right)_{3} \mathrm{P}$ (TBP)-based cations together with a bis (trifluoromethylsulfonyl) amide $\mathrm{N}\left(\mathrm{SO}_{2} \mathrm{CF}_{3}\right)_{2}$ (TFSA) anion, ${ }^{9,10)}$ and have explored their lithium battery application. ${ }^{11-13)}$ Tributylmethylphosphonium TFSA $\left(\mathrm{C}_{4} \mathrm{H}_{9}\right)_{3} \mathrm{CH}_{3} \mathrm{P}$ $\mathrm{N}\left(\mathrm{SO}_{2} \mathrm{CF}_{3}\right)_{2}\left(\mathrm{P}_{4441}-\mathrm{TFSA}\right)$ is one of the typical TFSAbased phosphonium compounds possessing favorable electrochemical stability for the use of lithium battery electrolytes. ${ }^{10)}$ Our preliminary investigation revealed that $\mathrm{P}_{4441}$-TFSA significantly improved the cycling performance of the lithium battery cell when added into a<smiles>CCPC(CC)(CC)CC</smiles><smiles>CCCCCC[P+](C)(C)c1ccccc1</smiles><smiles>CCCCCCCCCCCC</smiles><smiles>O=S(=O)(NS(=O)(=O)C(F)(F)F)C(F)(F)F</smiles>

$$
\mathrm{P}_{4444}{ }^{+}
$$

TFSA $^{-}$

Fig. 1 Structural illustration of ionic components of quaternary phosphonium salts investigated in this work. 
conventional organic electrolyte; ${ }^{14)}$ however, only $\mathrm{P}_{4441}$ TFSA has been tested. Therefore, extensive researches on the additive effects of the quaternary phosphonium compounds should be required.

In this paper, we report the additive effects of several quaternary phosphonium salts on the charge-discharge property of the lithium battery cells. In order to discuss the dependence of cation structures, three phosphonium cations are selected in this work: triethylpentylphosphonium $\left(\mathrm{P}_{2225}{ }^{+}\right)$, tributylmethylphosphonium $\left(\mathrm{P}_{4441}{ }^{+}\right)^{14)}$ and tetrabutylphosphonium $\left(\mathrm{P}_{4444}{ }^{+}\right)$cations (Fig. 1). Additionally, thermal stability of the cathode materials charged in the mixed electrolytes containing the phosphonium salts is also investigated.

\section{Experimental}

\subsection{Preparation of mixed electrolytes}

The synthesis and purification of quaternary phosphonium salts were performed according to the methods described in our previously published paper., ${ }^{9,10)}$ The mixed electrolytes containing the phosphonium salts were prepared by the same procedures reported previously. ${ }^{14)}$ One of the precursor phosphonium halides, triethylpentylphosphonium bromide $\left(\mathrm{C}_{2} \mathrm{H}_{5}\right)_{3} \mathrm{C}_{5} \mathrm{H}_{11} \mathrm{P}-\mathrm{Br}$, was synthesized by the nucleophilic addition of TEP (Nippon Chemical Industrial Co., Ltd., $20 \%$ toluene solution, trade name Hishicolin P-2) to 1-bromopentane (Tokyo Chemical Industry Co., Ltd.) at $80^{\circ} \mathrm{C}$ under nitrogen atmosphere. Tributylmethylphosphonium chloride $\left(\mathrm{C}_{4} \mathrm{H}_{9}\right)_{3}$ $\mathrm{CH}_{3} \mathrm{P}-\mathrm{Cl}$ and tetrabutylphosphonium chloride $\left(\mathrm{C}_{4} \mathrm{H}_{9}\right)_{4} \mathrm{P}-\mathrm{Cl}$ were supplied by Nippon Chemical Industrial Co., Ltd. (trade name Hishicolin ${ }^{\circledR} \mathrm{PX}-4 \mathrm{MC}$ and Hishicolin ${ }^{\circledR} \mathrm{PX}-4 \mathrm{C}$, respectively). The aqueous ion exchange reaction of the precursor phosphonium halides with Li-TFSA (Kanto Chemical Co., Inc.) at ambient temperature gave crude phosphonium TFSA salts $\left(\mathrm{P}_{2225}\right.$-TFSA, $\mathrm{P}_{4441}$-TFSA and $\mathrm{P}_{4444}$-TFSA). The resulting salts were extracted by dichloromethane and were purified by washing with pure water several times until no residual halide anion was detected with the use of $\mathrm{AgNO}_{3} . \mathrm{P}_{2225}$-TFSA and $\mathrm{P}_{4441^{-}}$ TFSA were viscous liquids at room temperature (socalled room-temperature molten salts or room-temperature ionic liquids) whereas $\mathrm{P}_{4444}$-TFSA was a crystalline solid (melting point: $83^{\circ} \mathrm{C}$ ). ${ }^{9,10}$ ) The residual content of halide anions $(<50 \mathrm{ppm})$ in each salt was checked by an ion chromatography. The lithium hexafluorophosphate $\left(\mathrm{LiPF}_{6}, 1.0 \mathrm{M}\right)$-ethylene carbonate (EC)-ethyl methyl carbonate (EMC) $(1: 2, \mathrm{v} / \mathrm{v})$ electrolyte $^{15)}$ was used as a conventional organic electrolyte (Ube Industries, Ltd.). The preparation of mixed electrolytes consisting of the phosphonium salts and the $\mathrm{LiPF}_{6}$-EC-EMC electrolyte was made in an argon atmosphere glove box $\left(\left[\mathrm{H}_{2} \mathrm{O}\right]<1 \mathrm{ppm}\right.$, $\left.\left[\mathrm{O}_{2}\right]<1 \mathrm{ppm}\right)$.

\subsection{Measurements of transport property}

The conductivity of each electrolyte was measured by using an ac impedance analyzer (Ivium Technologies, CompactStat) and a two Pt electrode conductivity cell (cell constant: $1.27 \mathrm{~cm}^{-1}$ ). The viscosity of each electrolyte was determined by using a vibration-type viscometer (CBC Materials Co. Ltd., VM-10A Laboratory Viscom- eter calibrated with the Brookfield Viscosity Standard). All measurements were performed under dry condition of argon flow at $25^{\circ} \mathrm{C}$.

\subsection{Lithium battery tests}

The lithium secondary batteries used for the chargedischarge tests were fabricated using conventional twoelectrode cells (CR2032). The fabrication of the lithium battery cells was carried out in an argon-atmosphere glove box $\left(\left[\mathrm{H}_{2} \mathrm{O}\right]<1 \mathrm{ppm},\left[\mathrm{O}_{2}\right]<1 \mathrm{ppm}\right)$. A paste mixture containing $\mathrm{LiCoO}_{2}$ (Nippon Chemical Industrial Co., Ltd., trade name Cellseed ${ }^{\circledR}$ C-5), conductive carbon black (Timcal, Super $\mathrm{P}^{\circledR}$ ) and poly(vinylidene fluoride) (PVDF, Kureha Co., W\#1300) was prepared with a weight ratio of 95:2.5:2.5. $N$-methylpyrrolidone (BASF Japan, Ltd.) was used as a dispersant for the paste mixture. The preparation of the cathode sheets (area: $1 \mathrm{~cm}^{2}$ ) was carried out by spreading the paste mixture onto an $\mathrm{Al}$ current collector (battery use, $99.5 \%$, Hosen Co., Ltd.). The content of the active material in the cathode sheet was $c a$. 7.2 $\mathrm{mg} \mathrm{cm}{ }^{-2}$. Li foils (area: $1 \mathrm{~cm}^{2}$, thickness: $0.5 \mathrm{~mm}$, Honjo Metal Co., Ltd.) were used as anodes. The polyethylene sheets (45 $\mu \mathrm{m}$ thick, Celgard Inc.) were employed as separators. The charge-discharge tests of the cells were conducted by using a charge-discharge system (Hokuto Denko Co., Ltd, HJR-110mSM6) at 4.2-3.4 V of cut-off voltage with $0.2-0.5 \mathrm{C}$ current rates at $25^{\circ} \mathrm{C}$. The cells were charged and discharged by a constant current/constant voltage (CCCV) and constant current (CC) modes, respectively.

\subsection{Thermal stability measurements of cathode}

All of the $\mathrm{LiCoO}_{2}$ cathode sheets for this measurement were basically prepared by the same procedure as described above. Each $\mathrm{LiCoO}_{2}$ cathode sheet was charged using a CR2032 coin-type cell (anode: Li metal) containing each mixed electrolyte at $4.3 \mathrm{~V}$ of voltage with $0.5 \mathrm{C}$ current rates $(5 \mathrm{~h})$. The $\mathrm{LiCoO}_{2}$ thus charged were removed from the cells and then were rinsed with a battery-grade dimethyl carbonate in an argon-atmosphere glove box $\left(\left[\mathrm{H}_{2} \mathrm{O}\right]<1 \mathrm{ppm},\left[\mathrm{O}_{2}\right]<1 \mathrm{ppm}\right)$. The thermograms of dried $\mathrm{LiCoO}_{2}$ samples were recorded by using a differential scanning calorimeter (Seiko Instruments Inc., DSC6200) with a heating rate of $2{ }^{\circ} \mathrm{C} \mathrm{min}^{-1}$ under nitrogen atmosphere.

\section{Results and Discussion}

\subsection{Transport property of mixed electrolytes}

In our preliminary study, an additive effect of $\mathrm{P}_{4441^{-}}$ TFSA into the $\mathrm{LiPF}_{6}$-EC-EMC electrolyte was remarkably observed at a volume ratio of $1: 1,{ }^{14)}$ so that the mixed electrolytes investigated in this work were prepared with the 1:1 volume ratio. Table 1 summarizes the transport property data (conductivity and viscosity) of various electrolytes at $25^{\circ} \mathrm{C}$. When each phosphonium salt was added into the $\mathrm{LiPF}_{6}$-EC-EMC electrolyte, the viscosity was increased and the conductivity was correspondingly decreased. In the three phosphonium salts, $\mathrm{P}_{2225}$-TFSA significantly gave the lowest viscosity and highest conductivity to its mixed electrolyte. However, there is a slight difference in the transport property between mixed $\mathrm{P}_{4441}$-TFSA and $\mathrm{P}_{4444}$-TFSA electrolytes, 
Table 1 Conductivity and viscosity of various electrolytes at $25^{\circ} \mathrm{C}$.

\begin{tabular}{|c|c|c|}
\hline Electrolyte & $\begin{array}{c}\sigma^{\mathrm{a}} \\
/ \mathrm{mS} \mathrm{cm}^{-1}\end{array}$ & $\begin{array}{c}\eta^{\mathrm{b}} \\
/ \mathrm{mPa} \mathrm{s} \\
\end{array}$ \\
\hline LiPF $_{6}-\mathrm{EC}-\mathrm{EMC}$ (no additive) ${ }^{\mathrm{c}}$ & $9.1^{14)}$ & $<10^{14)}$ \\
\hline Mixed $\mathrm{P}_{2225}-\mathrm{TFSA}$ electrolyte ${ }^{\mathrm{d}, \mathrm{e}}$ & 5.1 & 13 \\
\hline Mixed $\mathrm{P}_{4441}-\mathrm{TFSA}$ electrolyte ${ }^{\mathrm{d}, \mathrm{f}}$ & $3.6^{14)}$ & $16^{14)}$ \\
\hline Mixed $\mathrm{P}_{4444}$-TFSA electrolyte ${ }^{\mathrm{d}, \mathrm{g}}$ & 3.5 & 14 \\
\hline $\mathrm{P}_{2225}-\mathrm{TFSA}$ (neat) & $1.7^{9)}$ & $88^{9)}$ \\
\hline $\mathrm{P}_{4441}$-TFSA (neat) & $0.42^{10)}$ & $207^{10)}$ \\
\hline
\end{tabular}

${ }^{a}$ Conductivity at $25^{\circ} \mathrm{C}$.

${ }^{\mathrm{b}}$ Viscosity at $25^{\circ} \mathrm{C}$.

c $1.0 \mathrm{MLiPF}_{6} / \mathrm{EC}+\operatorname{EMC}(1: 2, \mathrm{v} / \mathrm{v})$.

${ }^{\mathrm{d}}$ Phosphonium salts/LiPF 6 -EC-EMC (1:1, v/v).

${ }^{\mathrm{e}} \mathrm{LiPF}_{6}: \mathrm{P}_{2225}-\mathrm{TFSA}=1.0: 2.8(\mathrm{~mol} / \mathrm{mol})$

${ }^{\mathrm{f}} \mathrm{LiPF}_{6}: \mathrm{P}_{4441}-\mathrm{TFSA}=1.0: 2.6(\mathrm{~mol} / \mathrm{mol})$

${ }^{g} \mathrm{LiPF}_{6}: \mathrm{P}_{4444}-\mathrm{TFSA}=1.0: 2.3(\mathrm{~mol} / \mathrm{mol})$

which seems to be due to their similar cation structures. Hence, it is thought that the transport property of the mixed electrolytes would be influenced by the cation sizes of added salts when the volume ratio of mixing is constant. The $\mathrm{P}_{2225}$ cation is smaller than $\mathrm{P}_{4441}$ and $\mathrm{P}_{4444}$ cations, which might be also supported by the comparison of their molar concentrations ( $\mathrm{P}_{2225}$-TFSA: $2.81 \mathrm{~mol}$ $\mathrm{dm}^{-3}$, P4441-TFSA: $2.57 \mathrm{~mol} \mathrm{dm}^{-3}$, at $25^{\circ} \mathrm{C}$ ), so that the mixed $\mathrm{P}_{2225}$-TFSA electrolyte exhibited relatively high transport property when compared to other mixed electrolytes.

\subsection{Charge-discharge property of lithium battery cells}

Figure 2 represents the charge-discharge curves of lithium battery cells containing the mixed phosphonium electrolytes in comparison with that containing the $\mathrm{LiPF}_{6}$-EC-EMC electrolyte with no additives. The discharge capacity and coulombic efficiency as a function of cycle number are also plotted in Fig. 3. All of the lithium battery cells containing the mixed phosphonium electrolytes exhibited typical charge-discharge behaviors. As shown in Fig. 2 (a), the cell containing the mixed $\mathrm{P}_{2225}$-TFSA electrolyte indicated sufficiently high discharge capacities (e.g. $160 \mathrm{mAh} \mathrm{g}^{-1}$ at the first cycle) with a high capacity retention ratio $(95 \%$ after $20 \mathrm{cy}$ cles). The coulombic efficiencies after the third cycle also approached $100 \%$ ( $c a .98-99 \%)$. It is noted that this cycling performance is superior to that of the cell containing the highly conductive $\mathrm{LiPF}_{6}$-EC-EMC electrolyte without adding $\mathrm{P}_{2225}$-TFSA (Fig. 2 (d)), which reveals that $\mathrm{P}_{2225}$-TFSA acts as an electrolyte additive for the improvement of cycling efficiency. However, in the case of the mixed $\mathrm{P}_{4441}$-TFSA electrolyte (Fig. 2 (b)), further favorable charge-discharge performance with relatively high capacity retention ratio ( $97 \%$ after 20 cycles) was observed despite the fact that the transport property of the mixed $\mathrm{P}_{4441}$-TFSA electrolyte is lower than that of the mixed $\mathrm{P}_{2225}$-TFSA electrolyte (Table 1). On the other hand, as shown in Fig. 2 (c), it is obvious that the cell containing the mixed $\mathrm{P}_{4444}$-TFSA electrolyte exhibited relatively low charge-discharge performance when com- pared to that containing the $\mathrm{LiPF}_{6}$-EC-EMC electrolyte without adding $\mathrm{P}_{4444}$-TFSA (Fig. 2 (d)).

The results given in Figs. 2 and 3 significantly suggest that both $\mathrm{P}_{2225}$-TFSA and $\mathrm{P}_{4441}$-TFSA were regarded as effective additives to improve the charge-discharge cyclability whereas $\mathrm{P}_{4444}$-TFSA reduced the cycling performance. Especially, in these phosphonium salts, $\mathrm{P}_{4441-}$ TFSA showed the most remarkable improving effect. It should be noted that additive behavior thus observed did not correspond to the transport property of the mixed electrolytes. However, the improving effect clearly depends on the structures of the phosphonium cations because both $\mathrm{P}_{4441}$ and $\mathrm{P}_{2225}$ cations are relatively asymmetrical when compared to the symmetrical $\mathrm{P}_{4444}$ cation. Therefore, the salts having asymmetrical phosphonium cations seem to play an important role in the vicinity of the electrode surface.

As a considerable possibility, this effect might be attributed to the uniform formation of lithium on the anode surface, suppressing the unfavorable formation of needle-like lithium dendrites to accumulate dead lithium area on the surface. Such a suppression of lithium dendrite formation by the phosphonium salts has also been suggested by Kohl and coworkers who examined the voltammetric behavior of tributylhexylphosphonium TFSA ${ }^{16)}$ In our preliminary investigation by using a cyclic voltammetry technique, it has been found that the mixed $\mathrm{P}_{4441}$-TFSA electrolyte gave a remarkable voltammetric response in deposition/dissolution processes of metallic lithium, ${ }^{14)}$ which seems to assist the above discussion of the effect on the anode surface. Additionally, it is well known that the formation of needle-like lithium dendrites on the anode surface can give short circuits, rendering the cells unsafe owing to the risk of fire and explosion. From this point of view, the additive performance of the phosphonium salts to suppress the lithium dendrite formation is thought to be of much practical significance for the safety performance as well as the charge-discharge cycling property of lithium secondary batteries.

Another possible effect seems to be on the $\mathrm{LiCoO}_{2}$ 

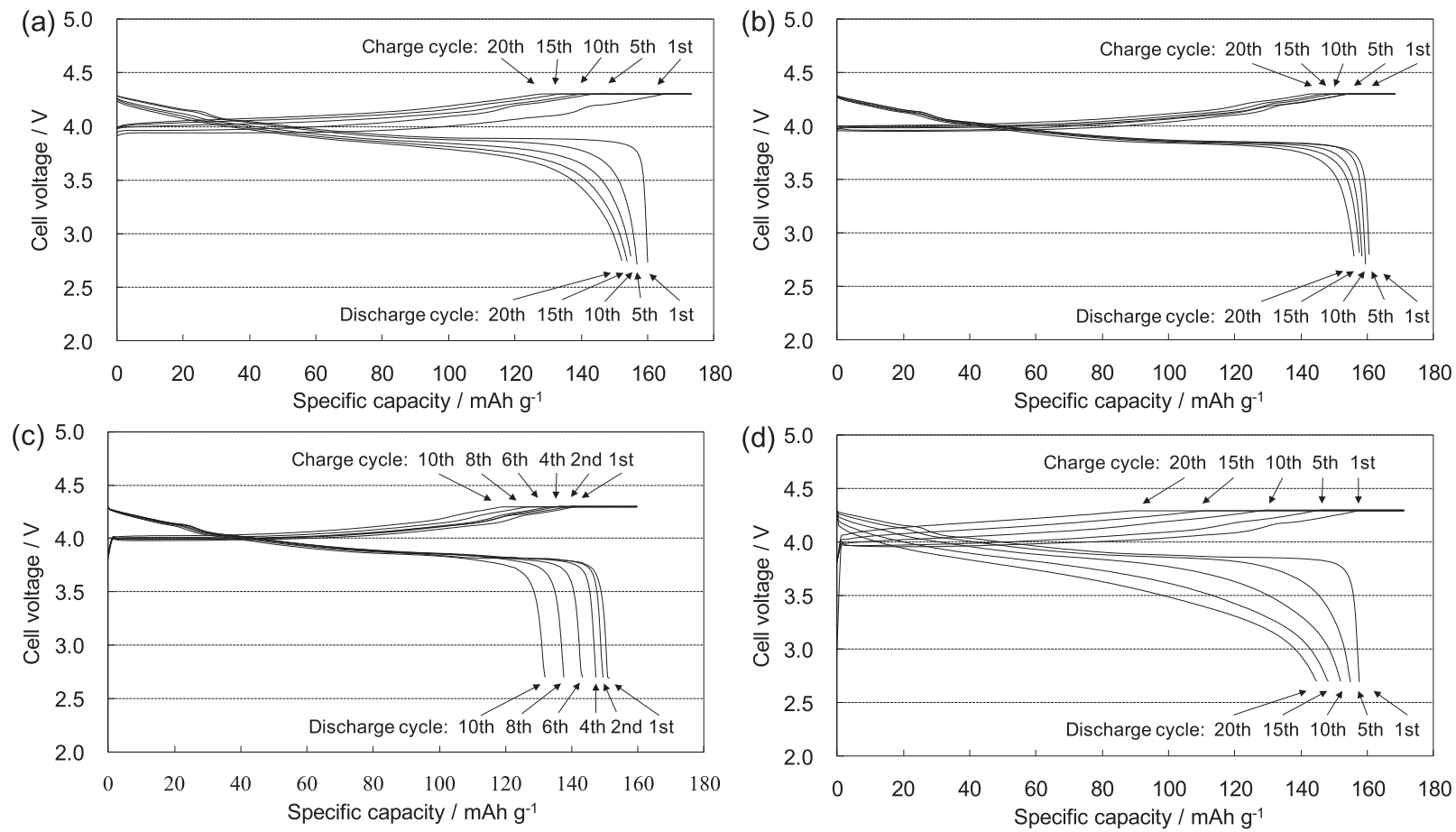

Fig. 2 The charge-discharge curves of $\mathrm{Li} /$ electrolytes $/ \mathrm{LiCoO}_{2}$ cells at $0.5 \mathrm{C}(\mathrm{CCCV}$ mode, $5 \mathrm{~h}, 0.56 \mathrm{~mA}$ $\mathrm{cm}^{-2}$ ) of charge current rate and at $0.2 \mathrm{C}\left(\mathrm{CC}\right.$ mode, $\left.0.22 \mathrm{~mA} \mathrm{~cm}^{-2}\right)$ of discharge current rate; the charge-discharge curves of the cells containing (a) the mixed $\mathrm{P}_{2225}$-TFSA electrolyte, (b) the mixed $\mathrm{P}_{4441}$-TFSA electrolyte, (c) the mixed $\mathrm{P}_{4444}$-TFSA electrolyte and (d) the LiPF $_{6}$-EC-EMC electrolyte (no additives). The data shown in (b) and (d) were taken from the reference. ${ }^{14)}$

(a)

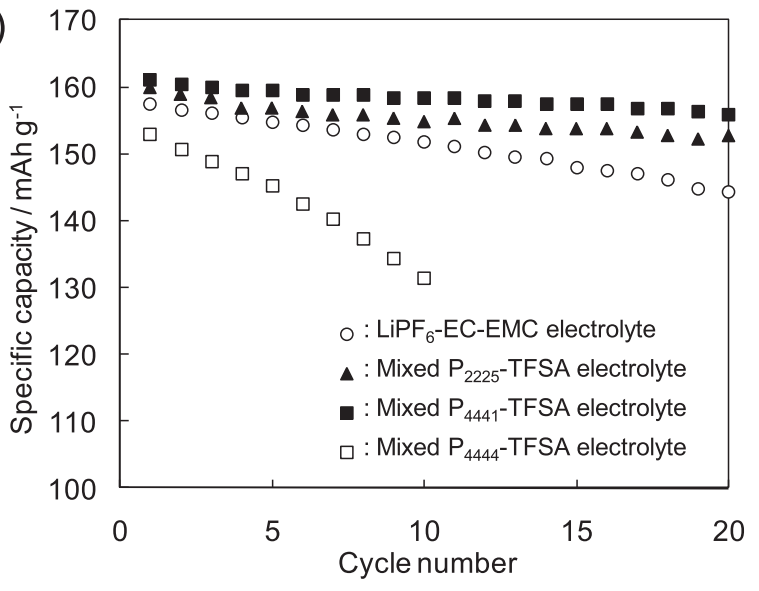

(b)

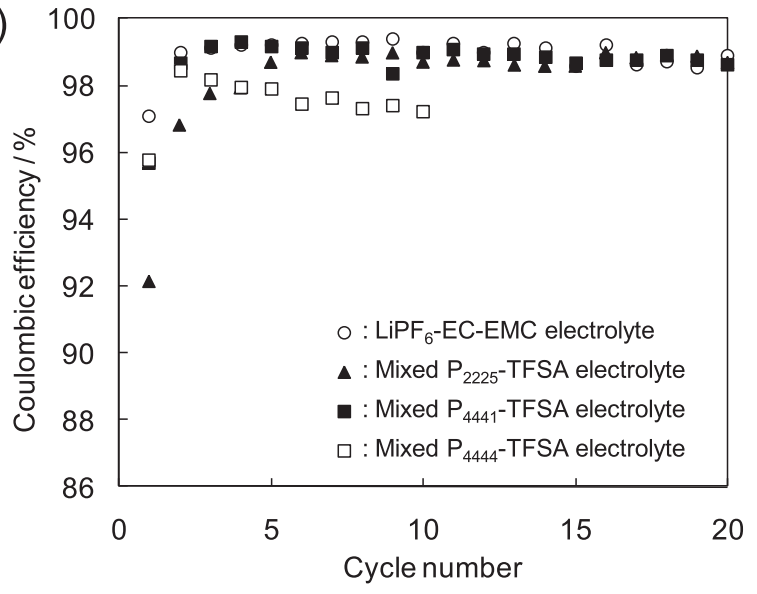

Fig. 3 Dependence of cycle number on (a) the discharge capacity and (b) the coulombic efficiency for the cells containing various electrolytes. cathode surface. It is well known that charge-discharge processes often involve the formation of a conductive passivation film, the so-called solid electrolyte interface (or solid electrolyte interphase) (SEI) film, to prevent further decomposition of the electrolytes. The specific effect of the phosphonium salts on the cell performance also might be attributed to the formation of a SEI-like film on the cathode surface; however, unfortunately at present we are unable to obtain clear information concerning the cathode surface. Further investigation of the SEI formation associated with the phosphonium salts should be required and will be conducted.

\subsection{Thermal stability of cathode}

Our additional attempt was made directly toward the effect of the phosphonium salts on the $\mathrm{LiCoO}_{2}$ cathode. Since it is well known that the phosphonium compounds possess high thermal stability, ${ }^{6,7)}$ we were motivated to investigate the thermal decomposition behavior of the cathode in the mixed phosphonium electrolytes. Figure 4 depicts the DSC thermograms of $\mathrm{LiCoO}_{2}$ cathodes charged in various electrolytes. As shown by dotted line in Fig. 4, the $\mathrm{LiCoO}_{2}$ cathode charged in the $\mathrm{LiPF}_{6}$-ECEMC electrolyte with no additives was thermally decomposed, exhibiting one large exothermic peak around 198 ${ }^{\circ} \mathrm{C}$ and two relatively small peaks at 204 and $240{ }^{\circ} \mathrm{C}$. It is worthwhile to note that, in the case of $\mathrm{LiCoO}_{2}$ cathodes charged in the mixed electrolyte containing the phosphonium salts $\left(\mathrm{P}_{2225}\right.$-TFSA and $\mathrm{P}_{4441}$-TFSA, solid and dashed lines, respectively), the peak around $198^{\circ} \mathrm{C}$ significantly vanished whereas the peak around $240^{\circ} \mathrm{C}$ grew larger. This means that the thermal decomposition 


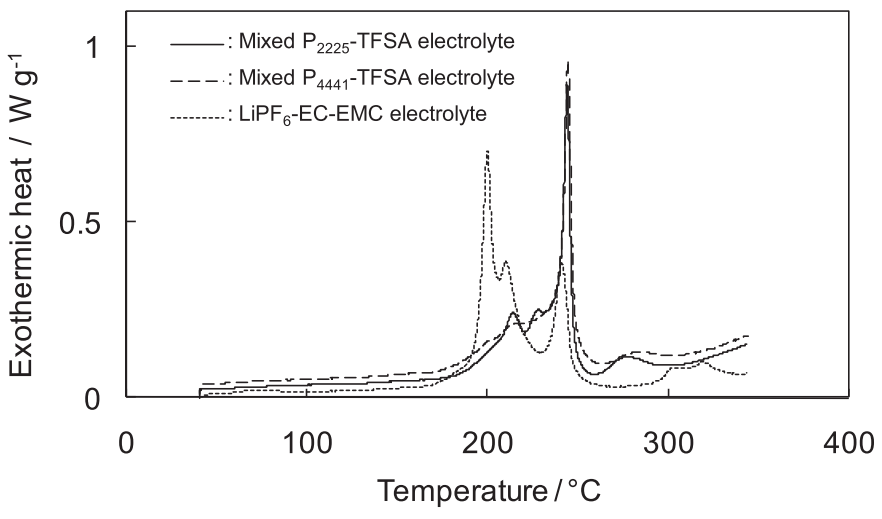

Fig. 4 DSC thermograms of $\mathrm{LiCoO}_{2}$ charged in mixed $\mathrm{P}_{2225}$-TFSA electrolyte (solid line), mixed $\mathrm{P}_{4441}$-TFSA electrolyte (dashed line) and $\mathrm{LiPF}_{6}$-EC-EMC electrolyte (dotted line).

points of $\mathrm{LiCoO}_{2}$ cathodes were shifted to relatively high temperature regions, indicating the thermal stabilization of $\mathrm{LiCoO}_{2}$ by the phosphonium salts. Although the detailed mechanism remains still unclear at present, such a thermal stabilization effect by the phosphonium salts should contribute to the safety performance of lithium battery cells.

\section{Conclusions}

We have shown the electrolyte additive properties of three phosphonium salts $\left(\mathrm{P}_{2225}\right.$-TFSA, $\mathrm{P}_{4441}$-TFSA and $\mathrm{P}_{4444}$-TFSA) on the charge-discharge property of lithium battery cells and the thermal stability of $\mathrm{LiCoO}_{2}$ cathode. The mixed electrolytes containing the phosphonium salts showed lower conductivities and higher viscosities than the $\mathrm{LiPF}_{6}$-EC-EMC electrolyte with no additives. Nevertheless, it was found that the charge-discharge cyclabilities of the cells containing the mixed phosphonium electrolytes based on asymmetrical cations $\left(\mathrm{P}_{2225}{ }^{+}\right.$and $\mathrm{P}_{4441}{ }^{+}$) were superior to that of the $\mathrm{LiPF}_{6}$-EC-EMC electrolyte. Especially, the mixed $\mathrm{P}_{4441}$-TFSA electrolyte gave relatively high cycling efficiency. Furthermore, the $\mathrm{LiCoO}_{2}$ cathodes charged in the mixed $\mathrm{P}_{2225}$-TFSA and
$\mathrm{P}_{4441}$-TFSA electrolytes were more thermally stable than that charged in the $\mathrm{LiPF}_{6}$-EC-EMC electrolyte. These results allow us to suggest that both $\mathrm{P}_{2225}$-TFSA and $\mathrm{P}_{4441^{-}}$ TFSA can be used as effective electrolyte additives to improve both the charge-discharge cycling performance of lithium battery cells and the thermal stability of $\mathrm{LiCoO}_{2}$ cathode. Additional and continuing investigations for lithium battery applications using quaternary phosphonium compounds are in progress and will be reported.

\section{References}

1) G. E. Blomgren, J. Power Sources, 119-121, 326 (2003).

2) K. Xu, Chem. Rev., 104, 4303 (2004).

3) S. S. Zhang, J. Power Sources, 162, 1379 (2006).

4) T. Hirai, I. Yoshimaru, and J. Yamaki, J. Electrochem. Soc., 141, 2300 (1994).

5) A. T. Ribes, P. Beaunier, P. Willmann, and D. Lemordant, J. Power Sources, 58, 189 (1996).

6) G. M. Kosolapoff, Organophosphorus Compounds, John Wiley \& Sons, New York, NY, p. 78 (1950).

7) C. J. Bradaric, A. Downard, C. Kennedy, A. J. Robertson, and Y. Zhou, Green Chem., 5, 143 (2003).

8) K. J. Fraser and D. R. MacFarlane, Aust. J. Chem., 62, 309 (2009).

9) K. Tsunashima and M. Sugiya, Electrochem. Commun., 9, 2353 (2007).

10) K. Tsunashima and M. Sugiya, Electrochemistry, 75, 734 (2007).

11) K. Tsunashima and M. Sugiya, Electrochem. Solid-State Lett., 11, A17 (2008).

12) K. Tsunashima, F. Yonekawa, and M. Sugiya, Chem. Lett., 37, 314 (2008).

13) K. Tsunashima, F. Yonekawa, and M. Sugiya, Electrochem. Solid-State Lett., 12, A54 (2009).

14) K. Tsunashima, F. Yonekawa, M. Kikuchi, and M. Sugiya, J. Electrochem. Soc., 157, A1274 (2010).

15) S. S. Zhang, T. R. Jow, K. Amine, and G. L. Henriksen, J. Power Sources, 107, 18 (2002).

16) J. A. Vega, J. Zhou, and P. A. Kohl, J. Electrochem. Soc., 156, A253 (2009). 